\title{
MEMPERTEGAS KEDUDUKAN HUKUM KESATUAN MASYARAKAT HUKUM ADAT DALAM MEMENUHI HAK- HAK KONSTITUSIONAL
}

\author{
Aullia Vivi Yulianingrum \\ aulliavivi@gmail.com \\ Dosen Fakultas Ilmu Sosial dan Humaniora Program Studi Ilmu Hukum \\ Universitas Muhammadiyah Kalimantan Timur
}

\begin{abstract}
ABSTRAK
Keberadaan dan hak-hak masyarakat hukum adat telah diterima dalam kerangka hukum tidak tertulis maupun hukum positif di Indonesia. Pada kenyataannya issue yang berkembang tentang kehadiran dan hak- hak masyrakat hukum adat adalah terbatasnya ruang dan gerak bagi komunitas-komunitas adat dalam mewujudkan demokratisasi pengelolaan wilayah adanya secara berkelanjutan, Konflik tenurial, keterbatasan dan kondisi kekayaan alam yang meliputi tanah dan kekayaan alam yang terkandung di dalamnya tidak asimetris dengan pertambahan penduduk. Sehingga perlu adanya penegasan kembali bahwa adanya korelasi antara Kesatuan Masyarakat Adat dengan Pemerintah terkait pemenuhan hak Konstitusionalnya yang terkandung dalam pasal Pasal 18B ayat (2), Pasal 28I ayat (3) dan Pasal 32 ayat (1) dan ayat (2) UUD NRI 1945 dimana aturan ini merupakan semangat otonomi yang diberikan seluas-luasnya kepada daerah. Ketentuan tersebut yang paling sering dirujuk ketika membicarakan mengenai keberadaan dan hak-hak masyarakat hukum adat. Kehadiran Mahkamah Konstitusi sebagai The Protector of the citizen's and Constitutional Rights and guardian of constitution juga memberikan secercah harapan bagi para pencari keadilan khususnya yang berkaitan dengan perlindungan terhadap hak masyarakat hukum adat
\end{abstract}

Kata Kunci: Hak- Hak Masyarakat Hukum Adat, Aturan, Mahkamah Konstitusi

\section{PENDAHULUAN}

Pengaturan mengenai keberadaan dan hak-hak masyarakat hukum adat di Indonesia terdapat di dalam UUD NRI Tahun 1945, Undang-Undang serta Peraturan perundang-undangan lainnya. Hal ini menunjukan bahwa keberadaan dan hakhak masyarakat hukum adat telah diterima dalam kerangka hukum tidak tertulis maupun hokum positif di Indonesia. Keberadaan masyarakat hukum adat sebagai subyek hukum memiliki perbedaan dengan subyek hukum lainnya. Hal ini sudah tampak sejak UUD 1945 periode pertama di mana pada bagian penjelasan UUD 1945 terdapat penjelasan mengenai

\begin{abstract}
"persekutuan hukum rakyat" yaitu masyarakat hukum adat yang keberadaannya sudah ada sebelum proklamasi Republik Indonesia. Dalam penjelasan UUD 1945 dituliskan bahwa:

"Dalam territoir Negara Indonesia terdapat lebih kurang 250 zelfbesturende landchappen dan volksgemenschappen, seperti desa di Jawa dan Bali, negeri di Minangkabau, dusun dan marga di Palembang dan sebagainya. Daerah-daerah itu mempunyai susunan asli, dan oleh karenanya dapat dianggap sebagai daerah yang bersifat istimewa.
\end{abstract}

Negara Republik Indonesia menghormati kedudukan daerah-daerah istimewa tersebut dan segala peraturan 
negara yang mengenai daerah-daerah itu akan mengingati hak-hak asal-usul daerah tersebut."

Kurnia Warman berpendapat, ketika dilakukan amandemen terhadap UUD 1945, bagian penjelasan UUD 1945 dihapus keberadaannya. Kemudian dasar hukum mengenai keberadaan masyarakat adat diletakkan pada Batang Tubuh UUD 1945. Setidaknya terdapat tidak tiga ketentuan utama dalam UUD 1945 yang dapat menjadi dasar bagi keberadaan dan hak-hak masyarakat hukum adat. Tiga ketentuan tersebut yaitu Pasal 18B ayat (2), Pasal 28I ayat (3) dan Pasal 32 ayat (1) dan ayat (2) UUD NRI $1945 .{ }^{1}$

\section{A. Isue Sosial dan Budaya}

1) UU Nomor 5 Tahun 1979 tentang Pemerintahan Desa adalah awal dari proses memarjinalisasikan hak-hak masyarakat adat, Undang- Undang Nomor 23 Tahun 2014 tentang Pemerintahan Daerah seyogjanya memberikan peluang yang lebih besar bagi komunitas lokal untuk lebih eksis dalam mempertahankan hak dasar adat, kenyataannya hanya merupakan ekspektasi kekuasaan dari Pemerintahan Pusat kepada Pemerintahan di Daerah yang secara langsung lebih membatasi ruang dan gerak bagi komunitas-komunitas adat dalam mewujudkan demokratisasi pengelolaan wilayah adanya secara berkelanjutan. Pengistilahan, Pengertian dan Kriteria Masyarakat dalam Peraturan Perundangundangan.

2) Konflik tenurial sebenarnya juga dapat di angap sebagai konplik antar system, yaitu system pengelolaan sumber daya agraria, dalam konplik

\footnotetext{
1 http://procurement-notices. undp. Org / view_file.cfm?doc_id=39284 diakses tanggal 2 Oktober 2017
}

ini dominasi negara dan pemodal sangat kuat bahkan sering disertai dengan kekerasan structural (structural violence). Konplik antar system ini juga diwarnai oleh upayaupaya dominasi melalui proses hegemoni pegetahuan dalam system pengelolaan sumber daya alam. ${ }^{2}$

3) Masalah pokok yang dihadapi setiap negara agraris adalah keterbatasan dan kondisi kekayaan alam yang meliputi tanah dan kekayaan alam yang terkandung di dalamnya tidak asimetris dengan pertambahan penduduk, kemajuan teknologi. Kondisi ini mengharuskan adanya strategi kebijakan dalam memelihara, melestarikan, memperuntukkan, mengambil manfaat, distribusi tanah Sumber Daya Alam termasuk hasilnya untuk kesejahteraan rakyat dan keberlangsungan

4) Efektivitas pengelolaan dan perlindungan kekayaan alam termasuk hutan akan terwujud melalui penerapan otonomi Kesatuan Masyarakat Hukum Adat untuk mengatur, merencanakan peruntukan, persediaan kekayaan alam/hutan dan memelihara hutan dalam wilayah ulayatnya berdasarkan aturan hukum adat. Dan Setiap Kesatuan Masyarakat Hukum Adat wajib mensosialisasi aturan hukum lokal yang mengatur hutan secara turun temurun, sehingga setiap generasi anggota masyarakat hukum adat memiliki pengetahuan untuk membedakan kategori kekayaan alam/hutan, pengetahuan tentang

\footnotetext{
2 Mengugat Posisi Masyarakat Adat Terhadap Negara, AMAN 1999 dalam http://www.akar.or.id/2015/11/23/rumusan-hasil seminar-dan-konsultasi-pengakuan-masyarakathukum-adat-dalam-sistem-ketatanegaraan-diindonesia/ diakses tanggal 10 juli 2017
} 
prosedur pemanfaatan hutan, pengetahuan perbuatan yang tabu terhadap kekayaan alam/hutan, dan pengetahuan tentang reaksi adat jika melanggar tabu/larangan.

5) Dalam program yang dilaksanakan harus mengubah paradigma pembangunan yang di lakukan oleh Negara dari pembangunan yang 'tranplantasi' menjadi 'transformasi'. Karena pembangunan yang tidak berakar pada kebudayaan komunitas masyarakat adat/local sebagai penguasa tanah secara turun temurun adalah kegiatan asing yang 'masuk tanpa izin'.

6) Model pembangunan yang baru harus dimulai dari masyarakat sebagai pengambil keputusan atas pengunaan tanah, prasyarat di pergunakannya tanah dan sumber daya alam lainnya yang berada di wilayah adalah informend concent dari komunitas, sehingga proses pengadaan tanah dan pemberian hak baru atas tanah haruslah masyarakat sungguhsungguh menyetujuinya, melalui partisipasi dalam pengambilan keputusan pada setiap tahapan pelepasan hak atas tanah.

7) upaya mendorong legalitas formal hak atas tanah sehingga kontroversi atas saling klain kepemilikan atas tanah kedepan tidak terulang kembali, tentunya proses ini harus difasilitasi oleh lembaga yang independent yang terlepas dari berbagai kepentingan.

\section{PERMASALAHAN}

Hukum adat (diakui atau tidak) adalah bersifat tradisional (terlepas dari perkembangannya) dan merupakan hukum yang ada (hidup) pada masa dahulu kala, bahkan sejak sebelum Indonesia merdeka.
Globalisasi, pada perjalanannya juga membutuhkan dan akan menjadikan hukum sebagai alat untuk memuluskan sekian banyak "produk" globalisasi dan modernisasi. Paradigma hukum yang match dengan kebutuhan tersebut adalah "hukum positif". Hukum positif, melalui azas legalitasnya yang dipegang kendali oleh Pemerintah mengharuskan adanya jaminan kepastian, dan kepastian itu hanya bisa didapat melalui pemikiranpemikiran yang rasional dan bukti-bukti yang empiric. Saat ini Secara realita ada indikasi potensi untuk merujuk kearah Sentralisme kekuasaan pusat dan pembatasan kewenangan pemerintah Daerah khususnya masyarakat Adat, Oleh karena itu penulis tertarik untuk mengkaji sejumlah aturan yang memaparkan kedudukan hukum Kesatuan Masyarakat Adat. Berdasarkan latar belakang tersebut maka, penulis membuat rumusan masalah dengan rincian sebagai berikut? :

1. Apa menjadi korelasi antara Kesatuan Masyarakat Adat dengan Pemerintah terkait pemenuhan hak Konstitusionalnya?

2. Apa upaya dilakukan oleh Mahkamah Konstitusi untuk memperkuat eksistensi Kesatuan Masyarakat Adat secara hukum?

\section{PEMBAHASAN}

\section{A. Korelasi Hukum Dan Kekuasaan Antara Negara Dan Kesatuan Masyarakat Adat (State Society Relation).}

1. Kedudukan Hukum

a. UUD 1945 Pasal 18B (2) Negara mengakui dan menghormati kesatuan-kesatuan MASYARAKAT HUKUM ADAT beserta hak-hak tradisionalnya SEPANJANG

MASIH HIDUP dan sesuai dengan 
perkembangan masyarakat dan prinsip Negara Kesatuan Republik Indonesia, yang diatur dalam undangundang.

b. UU Nomor 5 Tahun 1960 tentang UUPA, Pasal 2 ayat (4) UUPA menentukan bahwa "hak menguasai dari negara tersebut di atas pelaksanaannya dapat dikuasakan kepada daerah-daerah swatantra dan masyarakat-masyarakat hukum adat, sekedar diperlukan dan tidak bertentangan dengan kepentingan nasional, menurut ketentuanketentuan peraturan pemerintah". Ketentuan tersebut berkaitan dengan penyelenggaraan pemerintahan daerah. Pemberian kewenangan yang dimaksud merupakan upaya untuk memajukan kesejahteraan rakyat di daerah yang bersangkutan.

c. UU Nomor 5 Tahun 1990 tentang Konservasi Sumberdaya Alam Hayati Dan Ekosistemnya, pada Pasal 5 Konservasi sumber daya alam hayati dan ekosistemnya dilakukan melalui kegiatan:perlindungan sistem penyangga kehidupan, pengawetan keanekaragaman jenis tumbuhan dan satwa beserta ekosistemnya dan pemanfaatan secara lestari sumber daya alam hayati dan ekosistemnya.

d. UU Nomor 41 Tahun 1999 tentang Kehutanan, pada Pasal 36 (1) dan Pasal 37 (1) UU 41/1999 bahwa pemanfaatan hutan hak dan hutan adat dilakukan sesuai dengan fungsinya. Selanjutnya dalam ayat (2) disebutkan bahwa pemanfaatan hutan lindung dan konservasi di hutan hak maupun adat dapat dilakukan sepanjang tidak mengganggu fungsinya, sebagai berikut; Penting agar ketentuan ini dibaca secara $a$ contrario. Kalau kemudian hutan adat dan hutan hak berada di luar kawasan hutan, maka pemerintah tidak punya kewenangan untuk mengatur lagi apakah hutan yang ada di kelola sesuai fungsinya dan dengan demikian pengaturan tersebut mengisyaratkan bahwa pemerintah tetap harus mengatur fungsi dalam tiap penguasaan atas hutan, baik itu oleh hak maupun oleh adat.

e. UU Nomor 18 Tahun 2004 tentang Perkebunan. Salah satu yang diatur didalam undang-undang ini adalah keharusan bagi pihak yang mengajukan izin perkebunan untuk bermusyawarah terlebih dahulu (apabila sudah terdapat hak di atas tanah tersebut) dengan masyarakat atau masyarakat hukum adat (apabila tanah tersebut adalah tanah ulayat) sehingga sesuai dengan pengaturan tersebut, masyarakat memiliki sebuah landasan hukum untuk dapat berpartisipasi dalam proses pemberian izin perkebunan.

f. UU Nomor 26 Tahun 2007 tentang Penataan Ruang. Undang-Undang Penataan Ruang nomor 26 tahun 2007 yang menggantikan UndangUndang nomor 24 tahun 1992. Dalam UU 26/2007 penataan ruang ditujukan untuk mewujudkan ruang wilayah nasional yang aman, nyaman, produktif dan berkelanjutan. Dengan tujuan tersebut, penataan ruang pada akhirnya diharapkan menjadi sebuah titik temu yang harmonis antara penggunaan sumber daya alam dan dan pemanfaatan ruang sekaligus mencegah terjadinya dampak negatif akibat pemanfaatan ruang. Sifat mendasar dari penataan ruang adalah mewujudkan sebuah keterpaduan dan keserasian pemanfaatan ruang pada berbagai 
sektor sehingga

pelaksanaan penataan ruang yang konsisten akan meminimalisasi konflik dan meningkatkan keterpaduan antar sektor serta wilayah. Pada posisi ini Pemerintah pusat dan daerah diamanatkan untuk menyebarluaskan informasi rencana umum dan rincian tataruang, pengaturan zonasi dan petunjuk pelaksanaan penataan ruang. Penataan ruang diselenggarakan oleh pemerintah dengan melibatkan masyarakat, dimana pelibatan tersebut mencakup perencanaan, pemanfaatan dan pengendalian.

g. UU Nomor 27 Tahun 2007 tentang Pengelolaan Wilayah Pesisir dan Pulau-Pulau Kecil memberikan jaminan bagi pelestarian Masyarakat Adat dalam pemberian Hak Pengusahaan dan wajib mempertimbangkan kepentingan kelestarian Ekosistem Pesisir dan

Pulau-Pulau

Kecil, Masyarakat Adat, dan kepentingan nasional serta hak lintas damai bagi kapal asing. Selain itu dalampasal 18 juga dijelaskan dapat pula diberikan kepada Masyarakat Adat selain padaperorangan warga negara Indonesia dan badan hukum. Selanjutnya dalam Pasal 21 ayat (4) dijelaskan mengenai persyaratan operasional yang menjadi kewajiban pemegang hak penguasaan untuk mengakui, menghormati, dan melindungi hak-hak Masyarakat Adat dan /atau masyarakat local

h. UU Nomor 32 Tahun 2009 tentang Lingkungan Hidup, pada Pasal 1 hurup 30 menyebutkan bahwa Masyarakat Hukum Adat (MHA) adalah "kelompok masyarakat yang secara turun-temurun bermukim di wilayah geografis tertentu, karena adanya ikatan pada asal usul leluhur, adanya hubungan yang kuat dengan lingkungan hidup, serta adanya sistem nilai yang menentukan pranata ekonomi, politik, sosial, dan hukum" dan Kearifan lokal adalah nilai-nilai luhur yang berlaku dalam tata kehidupan masyarakat untuk antara lain melindungi dan mengelola lingkungan hidup secara lestar

i. UU Nomor 4 Tahun 2011 tentang Informasi Geospasial. Informasi geospasial yang tidak terintegrasi merupakan salah satu masalah utama dalam pengelolaan hutan. Informasi geospasial yang berbeda-beda antar instansi pemerintahan, baik antar sektor atau pun antar pusat dengan daerah, mengakibatkan adanya ketidaksinkronan antar kebijakan terkait penggunaan kawasan hutan dan lahan. Undang-undang ini melahirkan kebijakan One Map Policy sebagai alat koordinasi antar instansi dalam penyediaan informasi, termasuk antara instansi di pusat dan daerah.Disisi lain lewat informasi geospasial menjamin hak-hak warga negara secara ekonomi dalam hubungannya dengan keruangan, sebaliknya menjadi alat bantu pemerintah dalam perumusan kebijakan, pengambilan keputusan, dan pelaksanaan kegiatan yang berhubungan dengan keruangan.

j. UU Nomor 23 Tahun 2014 tentang Pemerintahan Daerah. Undangundang ini adalah pengganti dari Undang-Undang nomor 32/2004 tentang Pemerintah Daerah yang dianggap tidak sesuai lagi dengan perkembangan keadaan, ketatanegaraan dan tuntutan penyelenggaran pemerintahan daerah.Dalam undang-undang ini 
sektor kehutanan dikategorikan dalam urusan pemerintahan daerah pilihan konkuren (Pasal 12), meskipun urusan penataan ruang dan lingkungan hidup dikategorikan dalam urusan pemerintahan wajib. Dalam Pasal 14, diatur tentang penyelenggaraan urusan pemerintah dalam bidang kehutanan dibagi antara pemerintah pusat dan daerah provinsi dengan perkecualian pengelolaan taman hutan raya di kabupaten/kota menjadi kewenangan dari daerah kabupaten dan kota.

k. UU Nomor 6 Tahun 2014 tentang Desa, Terdapat lebih 33 ribu desa yang berbatasan dengan kawasan hutan, jika hal ini tidak menjadi perhatian maka masalah tenurial, status desa maupun kekayaan budaya yang selama ini dikenal memelihara dan melindungi akan bergeser dan punah. Desa Adat akan diakui apabila memiliki kesatuan masyarakat adat. Kesatuan masyarakat adat harus memiliki unsur; mempunyai wilayah adat, pemerintahan adat, benda/harta adat, hukum adat, sebagaimana yang dimaksud dalam pasal 1 ayat $1 \mathrm{UU}$ Desa. UU desa juga mengakui hakhak kesatuan masyarakat adat. Desa Adat bukan hanya bertujuan untuk mengakui hak-hak ulayat masyarakat adat, tetapi juga undang-undang ini mengatur agar masyarakata adat bisa mengurus dirinya sendiri. Pembentukan Desa ditetapkan dengan Peraturan Daerah Kabupaten/ Kota dengan mempertimbangkan prakarsa masyarakat desa, asal usul, adat istiadat, kondisi sosial budaya masyarakat desa, serta kemampuan dan potensi desa. Pemerintah pusat dan daerah akan melakukan penataan kesatuan masyarakat hukum adat untuk kemudian ditetapkan menjadi Desa Adat. ${ }^{3}$

Semangat yang dibangun dalam pasal Pasal 18B ayat (2), Pasal 28I ayat (3) dan Pasal 32 ayat (1) dan ayat (2) UUD NRI 1945 adalah semangat otonomi yang diberikan seluas-luasnya kepada daerah Tiga ketentuan tersebut yang paling sering dirujuk ketika membicarakan mengenai keberadaan dan hak-hak masyarakat hukum adat. Meskipun demikian tidak berarti bahwa dasar konstitusional bagi hak masyarakat hukum adat hanya pada tiga ketentuan tersebut. Masyarakat hukum adat sebagai bagian dari Warga Negara Indonesia juga memiliki hak-hak konstitusional sebagai warga negara misalkan untuk mendapatkan penghidupan yang layak, lingkungan yang baik, persamaan di hadapan hukum dan hak-hak lainnya. Khususnya pengelolaan Sumber Daya Alam atau disingkat SDA yang terinspirasi dari semangat founding fathers kita tentang pembangunan Indonesia secara utuh dan merata. Munculnya era globalisasi dengan modernisasi, ternyata memunculkan permasalahan kemanusiaan: moral, etika, kesusilaan, HAM dan lain-lain. Hal ini terjadi, antara lain, karena globalisasi, modernisme dan rasionalisme, cenderung mengabaikan "nurani", sehingga "pembangunan" menafikan keberadaan manusia sebagai makhluk yang memiliki nurani, harkat dan martabat yang tidak bisa diukur dengan materi, sehingga pembangunan justru menimbulkan permasalahan kemanusiaan.

${ }^{3}$ http://www.akar.or.id/2015/11/23/rumusa n-hasil-seminar-dan-konsultasi-pengakuanmasyarakat-hukum-adat-dalam-sistemketatanegaraan-di-indonesia/ diakses tanggal $10 \mathrm{Juli}$ 2017. 
B. Pengistilahan, Pengertian Dan Kriteria Masyarakat Hukum Adat Dalam Peraturan Perundang-Undangan

Berikut korelasi hukum pada aspek Pengistilahan, Pengertian dan Kriteria Masyarakat dalam Peraturan Perundang-undangan:

Tabel 1.

Pengistilahan, Pengertian dan Kriteria Masyarakat dalam Peraturan Perundang-undangan ${ }^{4}$

\begin{tabular}{|c|c|c|}
\hline No & Peraturan yang Mengatur & Istilah yang Digunakan, Definisi dan Kriteria \\
\hline 1 & $\begin{array}{l}\text { Pasal } 18 \text { B ayat } \\
\text { (2) UUD } 1945\end{array}$ & $\begin{array}{l}\text { Kesatuan masyarakat hukum adat } \\
\text { Kesatuan masyarakat hukum adat diakui: } \\
\text { 1. Sepanjang masih hidup } \\
\text { 2. Sesuai dengan perkembangan } \\
\text { 2. masyarakat } \\
\text { 3. Sesuai dengan prinsip Negara } \\
\text { 4. Kesatuan Republik Indonesia }\end{array}$ \\
\hline 2 & Putusan Mahkamah Konstitusi & $\begin{array}{l}\text { Kesatuan masyarakat hukum adat Suatu } \\
\text { kesatuan masyarakat hukum adat beserta hak- } \\
\text { hak tradisionalnya yang bersangkutan } \\
\text { secara de facto masih ada dan/ atau hidup } \\
\text { (actual existence), apabila setidak-tidaknya } \\
\text { mengandung unsur-unsur: } \\
\text { a) ada masyarakat yang warganya } \\
\text { b) memiliki perasaan } \\
\text { c) kelompok (in-group feeling); } \\
\text { d) ada pranata pemerintahan } \\
\text { e) adat; } \\
\text { f) ada harta kekayaan dan/atau } \\
\text { g) benda-benda adat; } \\
\text { h) ada perangkat norma hukum } \\
\text { i) adat; dan khusus bagi kesatuan masyarakat } \\
\text { hukum adat yang bersifat teritorial juga } \\
\text { terdapat unsur wilayah hukum adat tertentu. }\end{array}$ \\
\hline 3 & $\begin{array}{l}\text { UU Nomor } 41 \\
\text { Tahun } 1999 \\
\text { Tentang }\end{array}$ & $\begin{array}{l}\text { Masyarakat Hukum Adat Masyarakat hukum } \\
\text { adat memenuhi kriteria } \\
\text { 1. masyarakatnya masih dalam bentuk }\end{array}$ \\
\hline
\end{tabular}

4 Ibid dan Myrna A. Safitri dkk, Adat di Tangan Pemerintah Daerah(Panduan Penyusunan Produk Hukum Daerah Untuk Pengakuan dan Perlindungan Hak Masyarakat Hukum Adat (Epistema Institute, Jakarta, 2014) hal 1727 


\begin{tabular}{|c|c|}
\hline Kehutanan & $\begin{array}{l}\text { paguyuban (rechsgemeenschap) } \\
\text { 2. ada kelembagaan dalam bentuk } \\
\text { perangkat penguasa adatnya; } \\
\text { 3. ada wilayah hukum adat yang jelas; } \\
\text { 4. ada pranata hukum, khususnya } \\
\text { peradilan adat, yang masih ditaati; dan } \\
\text { masih mengadakan pemungutan } \\
\text { 5. hasil hutan di wilayah hutan sekitarnya } \\
\text { untuk pemenuhan kebutuhan hidup } \\
\text { sehari- hari. }\end{array}$ \\
\hline $\begin{array}{l}\text { UU Nomor } 27 \\
\text { Tahun } 2007 \\
\text { tentang } \\
\text { Pengelolaan } \\
\text { Wilayah Pesisir } \\
\text { dan Pulau- pulau } \\
\text { Kecil }\end{array}$ & $\begin{array}{l}\text { Masyarakat Adat, Masyarakat,tradisional, } \\
\text { Masyarakat local Undang- Undang ini membagi } \\
\text { masyarakat dalam tiga kategori: } \\
\text { 1. Masyarakat Adat adalah kelompok } \\
\text { Masyarakat Pesisir yang secara turun- } \\
\text { temurun bermukim di wilayah geografi } \\
\text { s tertentu karena adanya ikatan pada asal- } \\
\text { usul leluhur, adanya hubungan yang kuat } \\
\text { dengan Sumber Daya Pesisir dan Pulau- } \\
\text { Pulau Kecil, serta adanya sistem nilai yang } \\
\text { menentukan pranata ekonomi, politik, } \\
\text { sosial, dan hukum. } \\
\text { 2. Masyarakat Lokal adalah kelompok } \\
\text { Masyarakat yang menjalankan tata } \\
\text { kehidupan sehari-hari berdasarkan } \\
\text { kebiasaan yang sudah diterima sebagai } \\
\text { nilai-nilai yang berlaku umum tetapi tidak } \\
\text { sepenuhnya bergantung pada Sumber Daya } \\
\text { Pesisir dan Pulau-Pulau Kecil tertentu. } \\
\text { 3. Masyarakat tradisional adalah masyarakat } \\
\text { perikanan tradisional yang masih diakui } \\
\text { hak tradisionalnya dalam melakukan } \\
\text { kegiatan penangkapan ikan atau kegiatan } \\
\text { lainnya yang sah di daerah tertentu yang } \\
\text { berada }\end{array}$ \\
\hline $\begin{array}{l}\text { UU } 32 \text { Tahun } \\
2009 \text { tentang } \\
\text { Perlindungan } \\
\text { dan Pengelolaan } \\
\text { Lingkungan } \\
\text { Hidup }\end{array}$ & $\begin{array}{l}\text { Masyarakat Hukum Adat Masyarakat hukum } \\
\text { adat adalah kelompok masyarakat yang secara } \\
\text { turun temurun bermukim di wilayah geografi } \\
\text { tertentu karena adanya ikatan pada asal usul } \\
\text { leluhur, adanya hubungan yang kuat dengan } \\
\text { lingkungan hidup, serta adanya sistem nilai } \\
\text { yang menentukan pranata ekonomi, politik, } \\
\text { sosial, dan hukum. }\end{array}$ \\
\hline
\end{tabular}




\section{Upaya Mahkamah Konstitusi \\ Untuk Memperkuat Eksistensi Kesatuan Masyarakat Adat Secara Hukum.}

Kehadiran Mahkamah Konstitusi sebagai The Protector of the citizen's and Constitutional Rights and guardian of constitution juga memberikan secercah harapan bagi para pencari keadilan khususnya yang berkaitan dengan perlindungan terhadap hak masyarakat hukum adat. Bermula dari diberikannya kedudukan hukum (legal standing). ${ }^{5}$

Menurut Fajar Laksono Suroso ${ }^{6}$, Mahkamah Konstitusi RI terlibat dalam memberikan perlindungan terhadap hak konstitusional Masyarakat Hukum Adat. Hal-hal lain berada di cabang kekuasaan yang lain yakni Eksekutif. Meskipun dalam penegakan hukum dasar tertinggi itu tidak dapat dilakukan secara sendirian oleh kekuasaan kehakiman, perlu kolaborasi antar kekuasaan di Indonesia. Konstitusi hanya kalimat-kalimat yang tidak berarti apa-apa, tanpa adanya kesadaran oleh setiap orang untuk bersama-sama melakukan penerapan ${ }^{7}$.

5 Lihat Putusan Mahkamah Konstitusi Nomor 31/PUU-V/2007, tanggal 18 Juni 2008 dan Sekretariat Jenderal dan Kepaniteraan Mahkamah Konstitusi, Hukum Acara Mahkamah Kontitusi(Sekretariat Jenderal dan Kepaniteraan Mahkamah Konstitusi,Jakarta,2010)hal 10

6 Juru Bicara Mahkamah Konstitusi; Peneliti Pusat Penelitian dan Pengkajian Perkara Mahkamah Konstitusi; dan Doktor Ilmu Hukum Tata Negara dari Program Doktor IImu Hukum Universitas Brawijaya Sebagai Narasumber yang disampaikan saat Pemaparan Materi didokumentasikan kedalam notulensi pada kegiatan Kerja Sama Mahkamah Konstitusi dan Fakultas Hukum Universitas Mulawarman dengan bentuk acara Seminar Nasional "Perlindungan Terhadap Hak- Hak Konstitusional Masyarakat Hukum Adat" di Fakultas Hukum Universitas Mulawarman pada tanggal 28 september 2017

7. Sebagai Narasumber yang disampaikan saat Pemaparan Materi didokumentasikan kedalam notulensi pada kegiatan Kerja Sama Mahkamah Konstitusi dan Fakultas Hukum Universitas Mulawarman dengan bentuk acara Seminar Nasional
Bagi masyarakat hukum adat dapat mengajukan pengujian Undang-Undang terhadap Undang- Undang Dasar Negara Republik Indonesia 1945, sehingga masyarakat hukum adat yang merasa hak konstitusional (termasuk pula hak adat) nya dilanggar oleh suatu kebijakan pembentuk Undang-Undang dapat meminta keadilan kepada Mahkamah Konstitusi. Namun, lagi-lagi masih juga harus memenuhi syarat-syarat tertentu terlebih dahulu agar kesatuan masyarakat hukum adat memiliki kedudukan hukum (legal standing) untuk mengajukan permohonan pengujian Undang-Undang di Mahkamah Konstitusi karena tidak semua masyarakat hukum adat mempunyai kedudukan hukum dalam pengujian Undang-Undang ${ }^{8}$. Walaupun terkesan berat bagi sebuah masyarakat yang tradisional dan masih sangat sederhana, berharap dengan meningkatnya taraf kehidupan manusia, maka masyarat hukum adat pun dapat "melek hukum" dan mengerti akan bagaimana cara mempertahankan hak konstitusionalnya di hadapan Majelis Hakim Konstitusi. ${ }^{9}$

Sebagai contoh dibidang Perkebunan, Mahkamah Konstitusi dalam Putusan Nomor 55/PUU-VIII/2010 telah mencoba menggali dan menemukan nilainilai yang hidup dalam masyarakat dengan menyatakan tidak memiliki kekuatan hukum frasa "penggunaan tanah perkebunan tanpa izin adalah tindakan okupasi tanah tanpa seizin pemilik hak sesuai dengan peraturan pernundangundangan" dalam Pasal 21 Undang-Undang Nomor 18 Tahun 2004 tentang Perkebunan beserta Penjelasannya dan ketentuan pidana

"Perlindungan Terhadap Hak- Hak Konstitusional Masyarakat Hukum Adat" di Fakultas Hukum Universitas Mulawarman pada tanggal 28 september 2017

8 Ibid

9http://rahadianprimanugraha.blogspot.co.id /2016/01/problema-hukum-perlindungan-atashak.html diakses tanggal 10 Juli 2017. 
yang menyertainya. Mahkamah Konstitusi dalam pertimbangannya menyatakan bahwa. ${ }^{10}$

"Masalah pendudukan tanah tanpa izin pemilik sangatlah beragam sehingga penyelesaiannya seharusnya menurut pertimbangan-pertimbangan keadaan yang berbeda: kapan munculnya persoalan tersebut?; apakah pendudukan tanah tersebut merupakan cara memperoleh tanah menurut hukum adat?; apakah pendudukan tersebut karena keadaan darurat telah diijinkan oleh penguasa?; apakah pendudukan tersebut disebabkan batas wilayah penguasaan secara hukum adat dengan wilayah yang dikuasai langsung oleh negara tidak jelas?. Kasuskasus yang sekarang timbul di daerahdaerah perkebunan yang baru dibuka, sangat mungkin disebabkan oleh tiadanya batas yang jelas antara wilayah hak ulayat dan hak individual berdasarkan hukum adat dengan hak-hak baru yang diberikan oleh negara berdasarkan ketentuan perundang-undangan; Dengan demikian penjatuhan sanksi sebagaimana dimaksud Pasal 47 ayat (2) Undang-Undang a quo tidak tepat jika hal tersebut dikenakan terhadap orang yang menduduki tanah berdasarkan hukum adat karena timbulnya hak-hak adat adalah atas dasar ipso facto. Artinya seseorang membuka, mengerjakan dan memanen hasilnya atas kenyataan bahwa ia telah mengerjakan tanah tersebut secara intensif dalam waktu yang lama, sehingga hubungan seseorang dengan tanah semakin intensif, sebaliknya hubungan tanah dengan hak ulayat semakin lemah. Adapun pemberian hak-hak baru dalam bentuk hak guna usaha atau hak pakai berdasarkan ipso jure, yang mendasarkan diri pada ketentuan perundangundangan."

10 Lihat bagian Pendapat Hukum Putusan Mahkamah Konstitusi Nomor 55/PUU-VIII/2010, bertanggal 19 September 2011, hlm. 102-103.
Selain itu dibidang Kehutanan, dalam perkara Nomor 35/PUU-X/2012 mengenai pengujian Undang-Undang Nomor 41 Tahun 1999 tentang Kehutanan, Mahkamah Konstitusi juga berperan dalam melindungi hak masyarakat hukum adat. Pada pokoknya, terdapat 2 (dua) permasalahan utama yang harus dijawab oleh Mahkamah, pertama, mengenai hutan adat dan kedua mengenai pengakuan bersyarat terhadap keberadaan masyarakat adat. Putusan itu mengabulkan permohonan berkaitan dengan hutan adat, namun menolak permohonan untuk menghapuskan syarat-syarat pengakuan keberadaan masyarakat adat yang terdapat di dalam Undang - Undang Kehutanan. Dalam pertimbangannya, menurut Mahkamah Konstitusi, Undang- Undang Kehutanan yang selama ini memasukan hutan adat sebagai bagian dari hutan negara merupakan bentuk dari pengabaian terhadap hak-hak masyarakat adat dan merupakan pelanggaran konstitusi. Peryataan bahwa selama ini telah terjadi pengabaian semestinya membuat pemerintah semakin sadar untuk memulihkan hak-hak masyarakat adat yang selama ini 'dirampas' atau diabaikan. Selain itu, hutan adat dikeluarkan posisinya dari sebelumnya merupakan bagian dari hutan negara kemudian dimasukan sebagai bagian dari kategori hutan hak.

Dalam pertimbangan hukum selanjutnya, terkait dengan kategorisasi hutan yang di dalamnya terdapat hubungan hukum antara subjek hukum dengan hutan. Mahkamah Konstitusi kembali menegaskan bahwa ketentuan dalam Undang-Undang Kehutnan telah memperlakukan masyarakat hukum adat yang secara konstitusional sebagai subjek hukum terkait dengan hutan berbeda dengan subjek hukum yang lain. Hal tersebut dapat dilihat dari slah satu pertimbangan Mahkamah Konstitusi yang menyatakan: 
"Ada tiga subjek hukum yang diatur dalam UU Kehutanan, yakni negara, masyarakat hukum adat, dan pemegang hak atas tanah yang di atasnya terdapat hutan. Negara menguasai baik atas tanah maupun atas hutan. Pemegang hak atas tanah dimaksud juga memegang hak atas hutan, tetapi masyarakat hukum adat tidak secara jelas pengaturan tentang haknya atas tanah maupun hutan."

Perlakuan yang berbeda terhadap masyarakat adat itulah yang juga menjadi dasar bagi Mahkamah Konstitusi untuk menyatakan bahwa telah terjadi pengabaian terhadap hak masyarakat adat atas hutan. Selain itu, prinsip ini juga mempertegas status hutan yang terdiri dari hutan negara, hutan adat dan hutan hak perseorangan/badan hukum. Prinsip ini merupakan prinsip penguasaan vertikal dimana pihak yang menguasai tanah maka dia juga menguasai hak-hak yang ada di atas tanah.

Menurut penulis keberadaan masyarakat adat haruslah tunduk kepada batasan-batasan yang ditentukan di dalam konstitusi antara lain masyarakat adatnya masih ada, selaras dengan perkembangan zaman dan tidak bertentangan dengan prinsip Negara Kesatuan Republik Indonesia yang harus dimaknai bahwa keberadaan masyarakat adat bukan untuk memisahkan diri dari republik Indonesia, serta pengaturan terkait subjek hukum masyarakat adat, kriteria dan tata caranya diatur berdasarkan Undang-Undang.

Sampai saat ini mekanisme pengakuan bagi masyarakat hukum adat, serta kedudukannya dalam hukum positif di Indonesia. Karena apabila mengikuti konstruksi peraturan perundang-undangan yang sudah ada saat ini, maka mekanisme tersebut diserahkan kepada daerah dalam bentuk peraturan daerah yang, sebagaimana telah dijelaskan sebelumnya, hal tersebut tidak akan menyelesaikan masalah ${ }^{11}$. Perlindungan terhadap hak masyarakat hukum adat harus dikonstruksikan dalam kebijakan affirmative action, karena sekalipun pembangunan fisik telah menjadi bagian dari kegiatan keseharian masyarakat Indonesia, namun dibutuhkan pedoman (guidance) yang mengawasi dan mencegah segala bentuk penindasan terhadap kaum masyarakat yang dalam posisi kurang menguntungkan. Segala upaya yang telah dilakukan oleh Mahkamah Konstitusi melalui putusan-putusannya tersebut masih dalam lingkup kewenangan konstitusi, dengan perkataan lain, masih dibutuhkan pemahaman dan kemauan dari para pembentuk Undang-Undang dan penegak hukum untuk menindaklanjutinya agar segera terwujud suatu tatanan baru dalam bidang penegakan hak masyarakat hukum adat yang lebih menjamin kepastian hukum dan keadilan sesuai dengan konstitusi.

$$
\text { Menurut Fajar Laksono }
$$

Suroso. ${ }^{12}$ Hingga saat ini masih terjadi perdebatan terkait penentuan yang valid yang membutuhkan kerjasama berbagai pihak untuk menjawab penentuan status masyarakat hukum adat. Fakta hari ini adalah, putusan MK hari ini hanya berlandasakan kesadaran bagi para pihak untuk melaksanakan hasil putusan, sedangkan posisinya putusan Mahkamah Konstitusi ini mencerminkan kedudukan konstitusi sebagai sumber hukum tertinggi.

11 Myrna A. Safitri dkk, Adat di Tangan Pemerintah Daerah(Panduan Penyusunan Produk Hukum Daerah Untuk Pengakuan dan Perlindungan Hak Masyarakat Hukum Adat (Epistema Institute, Jakarta, 2014) hal 75-78

12 Sebagai Narasumber yang disampaikan saat Pemaparan Materi didokumentasikan kedalam notulensi pada kegiatan Kerja Sama Mahkamah Konstitusi dan Fakultas Hukum Universitas Mulawarman dengan bentuk acara Seminar Nasional "Perlindungan Terhadap Hak- Hak Konstitusional Masyarakat Hukum Adat" di Fakultas Hukum Universitas Mulawarman pada tanggal 28 september 2017. 
Di beberapa negara terdapat sanksi politik untuk menekan pihak yang tidak pro kepada putusan pengadilan, dijadikan rezim politik, dan ini telah berhasil dilakukan. Di Indonesia belum efektif dapat dilakukan.

Menurut Penulis, walaupun masih belum meneukan titik terang terhadap status masyarakat hukum adat. Mahakamah Konstitusi sudah mampu menempatkannya sebagai subjek hukum yang mampu menopang hak dan kewajiban selayaknya subyek hukum lainnya.

Berikut Implikasi Putusan, merupakan bentuk nyata kedudukan kesatuan masyarakat hukum adat: ${ }^{13}$

- ketentuan yang dibatalkan digantikan oleh hukum yang dihasilkan oleh MK,

- memulihkan kerugian konstitusional

- peringatan kepada pemerintah sebagai pihak yang bertanggung jawab atas pemenuhan hak-hak warga negara

- mengontrol, mengarahkan pembuatan peraturan perundang-undangan. (as the living constitution)

\section{PENUTUP}

\section{Kesimpulan}

Hukum adat bersifat tradisional dan merupakan hukum yang ada (hidup) masa dahulu dan masih ada ditengah masyarakat yang lazimnya berbentuk kebiasaan, bahkan sejak sebelum Indonesia merdeka. Pada perjalanannya saat ini, adat membutuhkan hukum tertulis sebagai alat untuk memperoleh legitimasi dari penguasa dalam hak pengakuan serta perlindungan oleh hukum positif itu sendiri. Secara rinci, aturan terkait pengakuan dan perlindungan Sumber daya alam, wilayah dan kebiasaan

\footnotetext{
13 Makalah ini disampaikan padaSeminar Nasional "Perlindungan Hak Konstitusional Masyarakat Hukum Adat" yang diselenggarakan atas kerjasama Mahkamah Konstitusi dengan Fakultas Hukum Universitas Mulawarman, Samarinda, 28 September 2017.
}

yang berlaku pada masyarakat adat masih belum diatur sepenuhnya. Tetapi hukum positif Indonesia saat ini sudah mengatur terkait perselisihan ketika adanya hubungan hukum antar penguasa dan masyarakat hukum adat,dimana prosedur penyelesaiannya melalui upaya hukum dalam bentuk penanggulangan yang diselesaikan oleh Mahkamah Konstitusi untuk memperkuat eksistensi Kesatuan Masyarakat Adat sebagai subjek hukum.

\section{Saran}

Negara perlu menunjukan keberadaan dan hak-hak masyarakat hukum adat menerima hokum adat dalam kerangka hokum tidak tertulis maupun hokum positif dalam ketentuan memelihara keberadaan masyarakat hokum adat dan penanggulangan konfik.

Mahkamah Konsitusi sebagai pengawal konstitusi tetap konsisten dalam memberikan putusan yang berimplikasi memulihkan hak- hak konstitusional masyarakat hokum adat

\section{DAFTAR PUSTAKA}

\section{Buku}

Myrna A. Safitri dkk, Adat di Tangan

Pemerintah Daerah (Panduan

Penyusunan Produk Hukum Daerah

Untuk Pengakuan dan Perlindungan

Hak Masyarakat Hukum Adat

(Epistema Institute, Jakarta, 2014) hal 75-78

Sekretariat Jenderal dan Kepaniteraan

Mahkamah Konstitusi, Hukum Acara

Mahkamah Hukum Acara Mahkamah

Kontitusi (Sekretariat Jenderal dan

Kepaniteraan Mahkamah

Konstitusi, Jakarta, 2010)

\section{Literatur online}


http://procurementnotices.undp.org/view_fi le.cfm?doc_id=39284 diakses tanggal 2 Oktober 2017

Mengugat Posisi Masyarakat Adat Terhadap Negara, AMAN 1999 dalam http://www.akar.or.id/2015/11/23/rumusanhasil-seminar-dan-konsultasi-pengakuanmasyarakat-hukum-adat-dalam-sistemketatanegaraan-di-indonesia/diakses tanggal 10 juli 2017

http://www.akar.or.id/2015/11/23/rumusanhasil-seminar-dan-konsultasi-pengakuanmasyarakat-hukum-adat-dalam-sistemketatanegaraan-di-indonesia/diakses tanggal 10 Juli 2017.

http://rahadianprimanugraha.blogspot.co.id/ 2016/01/problema-hukum-perlindunganatas-hak.html diakses tanggal 10 Juli 2017.

\section{Putusan Mahkamah Konstitusi}

Lihat bagian Pendapat Hukum Putusan

Mahkamah Konstitusi Nomor 55/PUU-VIII/2010, bertanggal 19

September 2011.

Lihat Putusan Mahkamah Konstitusi

Nomor 31/PUU-V/2007, tanggal 18 Juni 2008

\section{Makalah/ Artikel}

Makalah ini disampaikan padaSeminar Nasional "Perlindungan Hak Konstitusional Masyarakat Hukum Adat" yang diselenggarakan atas kerjasama Mahkamah Konstitusi dengan Fakultas Hukum Universitas Mulawarman, Samarinda, 28 September 2017. 